\title{
Pengawetan Ekstrak Zat Warna Alami dari Gambir (Uncaria gambir) dalam Pelarut Air
}

\author{
Edia Rahayuningsih ${ }^{1, *}$, Wiratni Budhijanto ${ }^{1}$, Rizal I. Rosyid ${ }^{1}$, Yosephine I. Ayuningtyas ${ }^{1}$ \\ ${ }^{1}$ Grup Riset Teknik Bioproses, Departemen Teknik Kimia, Fakultas Teknik, Universitas Gadjah Mada, Jl. Grafika 2 \\ Yogyakarta 55281 \\ *e-mail: edia_rahayu@ugm.ac.id
}

\begin{abstract}
Abstrak. Tujuan penelitian ini adalah untuk menentukan jenis dan jumlah bahan pengawet yang secara efektif dapat menghambat reaksi biodegradasi zat warna alami dalam ekstrak gambir (Uncaria gambir) dalam pelarut air, serta menentukan nilai parameter reaksi biodegradasi zat warna alami dalam ekstrak gambir. Ekstrak zat warna alami dari gambir, yang telah bebas padatan, sebanyak $300 \mathrm{~mL}$ ditambah asam sitrat (0,006 gram/mL ekstrak) sebagai bahan bahan pengawet. Ekstrak kemudian disimpan dalam reaktor yang ditutup rapat dan dilindungi dari sinar ultra violet. Setiap selang waktu 2 hari, kadar pewarna alami dianalisis dengan metode gravimetri. Percobaan dilakukan dengan cara yang sama untuk 5 jenis pengawet lainnya dan dengan berbagai konsentrasi, yaitu: larutan formalin dalam air, larutan kitosan dalam asam asetat, ekstrak temu kunci (Boesenbergia rotunda L.), ekstrak daun salam (Syzygium polyanthum), dan ekstrak daun bandotan (Ageratum conyzoides L.), masing-masing sebanyak 5 $m L$ larutan atau ekstrak bahan pengawet dalam $40 \mathrm{~mL}$ sampel ekstrak. Berdasarkan penelitian ini dapat ditetapkan bahwa larutan formalin dalam air dan larutan kitosan dalam larutan asam asetat 2\% merupakan pengawet yang paling efektif menghambat reaksi biodegradasi zat warna alami dalam ekstrak, dibandingkan pengawet lainnya, yaitu: asam sitrat, ekstrak daun salam, ekstrak temu kunci, dan ekstrak daun bandotan. Jumlah formalin dan kitosan yang ditambahkan dalam ekstrak paling efektif berturut-turut adalah 0,017\% dan 0,25\% v/v. Nilai parameter reaksi biodegradasi zat warna alami dalam ekstrak diperoleh dalam bentuk konstanta kecepatan pertumbuhan spesifik ( $\mu_{0}$, hari $\left.^{-1}\right)$, konstanta saturasi $(K s, g / m L)$, konstanta kematian $\left(k_{d}\right.$, hari $\left.{ }^{-1}\right)$, rasio $k_{d} / \mu_{0}$, dan yield (Yi).
\end{abstract}

Kata kunci: biodegradasi, gambir, pengawet, pewarna alami.

Abstract. Preservation of Natural Dye Extract from Gambir (Uncaria gambir) in Water as Solvent. The purpose of this study was to determine the type and the amount of preservative agent which effectively prevent biodegradation reaction of natural colorant in the aqueous extract of "gambir" (Uncaria Gambir). This study also determined the parameter values in the biodegradation reaction of gambir extract. The experiment was carried out by first preparing $300 \mathrm{~mL}$ of filtered gambir extract, into which citric acid as much as $0.006 \mathrm{~g} / \mathrm{mL}$ was added as a preservative. The extract was then stored in a closed reactor with UV protector. Every two days, sample was drawn from the reactor for gravimetric analysis to determine the colorant concentration. Besides citric acid, the same experiments were also conducted for five other preservatives, which were the aqueous formaldehyde solution, the chitosan dissolved in 2\% acetic acid solution, the extract of "temu kunci" (Boesenbergia rotunda L.), the extract of Indian bay leaf (Syzygium polyanthum), and the extract of "bandotan leaf" (Ageratum conyzoides L.). This study showed that aqueous formaldehyde solution and chitosan dissolved in $2 \%$ acetic acid solution was the most effective preservative to prevent biodegradation reaction of natural colorant in gambir extract, in comparizon to citric acid, "temu kunci", Indian bay leaf, and "bandotan" leaf. The effective concentrations of formalin and chitosan were $0.017 \%$ and $0.25 \% \mathrm{v} / \mathrm{v}$ respectively. The parameters of the biodegradation reaction of the natural colorant in gambir extract in the form of specific growth rate coefficient ( $\mu$, day $\left.{ }^{-1}\right)$, saturation constant $\left(K_{s}, g / m L\right)$, death constant $\left(k_{d}, d a y^{-1}\right)$, ratio of $k_{d} / \mu$, and yield $\left(Y_{i}\right)$.

Keywords: biodegradation, gambir, natural dye, preservative.

\section{Graphical Abstract}

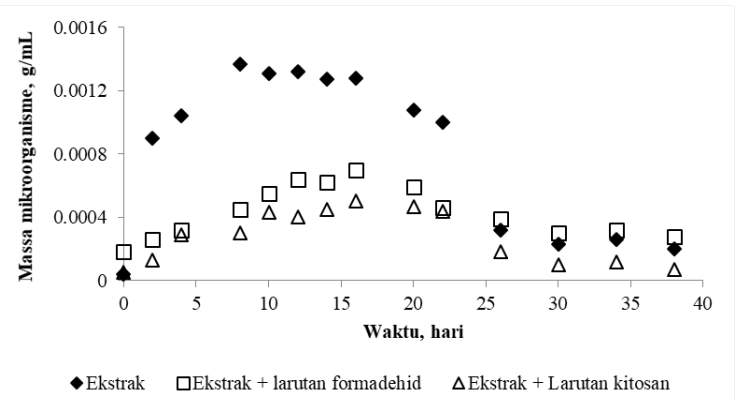




\section{Pendahuluan}

Gambir (Uncaria gambir) merupakan salah satu komoditas perkebunan Indonesia, hampir 80\% gambir yang dihasilkan Indonesia diekspor (Nazir, 2000). Getah gambir mengandung tanin sebesar 24,56\%, sehingga potensial digunakan sebagai bahan penyamak kulit dan juga bahan pewarna kain (Dhalimi, 2006). Komponen utama gambir adalah asam katekin (katekin) dan asam katekin tannat (katekin anhidrat). Jika katekin mengalami pemanasan atau pemanasan dalam larutan basa dengan mudah akan menjadi katekin tannat dan menjadi mudah larut dalam air (Hayani, 2003). Katekin merupakan senyawa tanin. Berdasarkan struktur molekul dan aktivitasnya terhadap senyawa hidrolitik terutama asam, tanin dapat dikelompokkan menjadi dua yaitu, tanin terhidrolisis dan tanin terkondensasi (Hagerman dkk., 1992). Tanin adalah senyawa polidroksil fenol, jika gugus fenol terdapat pada tanin terhidrolisis disebut pirogalol, sedangkan jika gugus fenol terdapat pada tanin terkondensasi disebut katekol (Hasanudin dkk., 2001).<smiles></smiles>

Gambar 1. Senyawa tanin<smiles>Oc1cc(O)c2c(c1)O[C@H](c1ccc(O)c(O)c1)[C@H](O)C2</smiles>

Gambar 2. Senyawa katekin<smiles>Oc1cccc(O)c1O</smiles>

Gambar 3. Struktur pirogalol<smiles>Oc1ccccc1O</smiles>

Gambar 4. Struktur katekol

Tanin merupakan senyawa polifenol, dengan demikian mampu menghambat proses oksidasi. Tanin merupakan senyawa yang bersifat polar sehingga dapat larut dalam air dan pelarut polar lainnya. Tanin yang terdapat pada gambir adalah golongan katekol tanin, bersifat asam lemah dan tidak mudah terhidrolisis. Tanin terkondensasi dalam tumbuhan lebih banyak keberadaannya daripada tanin terhidrolisis. Tanin terkondensasi merupakan polimer flavan triol atau flavan 3,4 diol atau kombinasi dari keduanya (Arunachalam dkk., 2003). Tanin terkondensasi lebih resisten terhadap dekomposisi mikroba daripada tanin terhidrolisis dan bersifat toksik pada jenis mikroorganisme tertentu (Arunachalam dkk., 2003).

Meskipun secara teoritis tanin terkondensasi resisten terhadap dekomposisi mikroba dan bersifat toksik pada jenis mikroorganisme tertentu, tetapi pada saat aplikasi ekstrak katekin dari gambir timbul beberapa keluhan dari para pengrajin batik dan tenun. Pada saat aplikasi ekstrak katekin dalam air sebagai pewarna kain, adalah mudah tumbuh jamur selama penyimpanan ekstrak dan pada saat diaplikasikan pada kain. Hal ini sangat mungkin karena kandungan tanin dalam getah gambir sebesar 24,56 \% (Dhalimi, 2006), kandungan senyawa lain dalam ekstrak dapat menjadi media pertumbuhan mikroorganisme. Untuk itu usaha pengawetan ekstrak dan usaha menghambat pertumbuhan mikroorganisme pada saat diaplikasikan dalam kain perlu diteliti. Dengan demikian dapat membantu menyelesaikan masalah yang dihadapi para pengrajin. Pada penelitian ini dikaji berbagai jenis dan jumlah bahan pengawet yang diharapkan dapat menghambat pertumbuhan mikroorganisme, serta laju reaksi biodegradasi untuk jenis dan jumlah bahan pengawet optimum.

Berdasarkan kajian pustaka diketahui ada beberapa senyawa alami dan sintetis yang potensial digunakan sebagai bahan pengawet, yaitu: kitosan merupakan senyawa polisakarida alami dan merupakan kopolimer dengan N-asetil-D-glukosamin dan Dglukosamin bersifat antioksidan, antitumor, antijamur, dan antibakteri (Younes dan Rinaudo, 2015). Larutan kitosan dalam asam asetat dengan konsentrasi 0,015\% terhadap volume total ekstrak kulit buah jelawe efektif dalam menghambat reaksi biodegradasi pewarna alami dalam ekstrak kulit buah jelawe dengan pelarut air (Rahayuningsih dkk., 2016). Rimpang temu kunci (Boesenbergia pandurata) mengandung $\gamma$-terpinene, geraniol, dan 2-champanone, yang merupakan jenis senyawa terpen. Senyawa terpen memberikan efek terhadap membran bakteri sehingga ekstrak dari tanaman ini memiliki sifat antimikroba, antioksidan, antikanker, dan menstimulasi sistem imun (Norajit dkk., 2007). Daun salam (Eugena polyantha) 
merupakan tumbuhan tropis yang berasal dari suku Myrtaceae. Ekstrak dari daun salam terbukti memiliki aktivitas antibakteri dan antijamur (Grosvenor dkk., 1995; Guynot dkk., 2005; Sumono dan Wulan, 2008). Asam sitrat adalah asam organik lemah yang ditemukan pada daun dan buah genus Citrus (jerukjerukan). Senyawa ini merupakan bahan pengawet yang baik dan alami, selain digunakan sebagai penambah rasa masam pada makanan dan minumam ringan. Zat ini juga dapat digunakan sebagai zat pembersih yang ramah lingkungan dan sebagai antioksidan. Daun Bandotan (Ageratum conyzoides) merupakan sejenis gulma pertanian dari suku Asteraceae. Ekstrak dari daun tumbuhan ini berupa minyak esensial yang mampu menghambat zat aflatoksin dari bakteri dan sebagai antijamur (Adjou dkk., 2012). Formalin (formaldehida) dapat digunakan untuk membasmi dan juga sebagai bahan pengawet. Larutan formalin dalam air dengan konsentrasi $0,125 \%$ terhadap volume total ekstrak kulit buah jelawe efektif menghambat reaksi biodegradasi pewarna alami dalam ekstrak kulit buah jelawe dengan pelarut air (Rahayuningsih dkk., 2016).

Pada saat penyimpanan dan aplikasi, ekstrak katekin dalam air terjadi proses alamiah. Proses alamiah tersebut berupa reaksi abiotik dan biotik. Reaksi abiotik yang terjadi antara lain reaksi oksidasi, hidrolisis, dan fotolisis, serta reaksi biotik atau disebut biodegradasi. Senyawa polifenol dalam tanin mampu menghambat proses oksidasi. Tanin yang terdapat pada gambir adalah golongan katekol tanin, bersifat asam lemah dan tidak mudah terhidrolisis. Adapun reaksi fotolisis bisa dihindari dengan kemasan yang baik. Untuk itu terjadinya reaksi abiotik pada ekstrak katekin dalam air dapat diabaikan. Tidak demikian halnya dengan reaksi biotik, karena kenyataannya pada penyimpanan dan aplikasi ekstrak gambir tumbuh jamur. Meskipun tanin terkondensasi dalam tumbuhan lebih banyak keberadaannya daripada tanin terhidrolisis dan tanin terkondensasi resisten terhadap dekomposisi mikroba. Akan tetapi resistensi tanin terkondensasi hanya terhadap jenis mikroba tertentu. Untuk itu terjadinya reaksi biodegradasi masih sangat dimungkinkan.

Menurut Rahayuningsih dkk. (2016) laju pertumbuhan biomassa dan laju reaksi penurunan konsentrasi pewarna alami dari kulit buah Jalawe dapat dinyatakan dengan persamaan sebagai berikut:

$$
\begin{aligned}
& r_{c}=\frac{\mu_{o} C_{s} C_{c}}{K_{s}+C_{s}}-k_{d} C_{c} \\
& r_{s}=\frac{1}{Y_{i}} r_{c}
\end{aligned}
$$

Dalam sistem batch, penurunan konsentrasi substrat dan peningkatan konsentrasi biomassa dapat dinyatakan dengan persamaan berikut:

$$
\begin{aligned}
& \frac{d C_{s}}{d t}=-r_{s} \\
& \frac{d C_{c}}{d t}=r_{c}
\end{aligned}
$$

dengan keadaan batas:

$t=0, C_{s}=C_{s 0}$ dan $C_{c}=C_{c 0}$

Perubahan konsentrasi substrat dan konsentrasi biomassa terhadap waktu dapat dihitung dengan persamaan simultan (1), (2), (3), (4), dan (5), untuk nilai $\mu_{0}, K_{s}, k_{d}$ and $Y_{i}$, yang diketahui. Persamaan diferensial ordiner simultan tersebut dapat diselesaikan menggunakan metode Runge-Kutta (Sediawan dan Prasetya, 1997). Dengan demikian nilai $\mu_{0}, K_{s}, k_{d}$ dan $Y_{i}$, yang merupakan parameter tidak dapat diukur, dapat ditentukan dengan cara pencocokan kurva antara konsentrasi substrat dan konsentrasi biomassa sebagai fungsi waktu hasil percobaan dan perhitungan menggunakan persamaan simultan (1), (2), (3), (4), dan (5) diatas.

\section{Metodologi}

Percobaan dilakukan pada reaktor batch yang terbuat dari botol kaca berwarna gelap dan diselimuti dengan aluminium foil agar terhindar dari sinar sehingga terjadinya reaksi fotolisis dan penguapan dapat diminimasikan.

Sebanyak $400 \mathrm{~mL}$ ekstrak zat warna alami dari gambir dengan pelarut air disentrifugasi, sehingga padatan yang ada dalam ekstrak dapat dipisahkan. Diambil $300 \mathrm{~mL}$ ekstrak gambir bebas padatan dimasukan dalam reaktor dan ditambah asam sitrat sebagai bahan bahan pengawet, konsentrasi asam sitrat yang ditambahkan sebanyak $0,006 \mathrm{gram} / \mathrm{mL}$ ekstrak. Setiap selang waktu 2 hari diambil $10 \mathrm{~mL}$ larutan dari reaktor kemudian disentrifugasi dengan kecepatan 3500 rpm selama 20 menit. Beningan diambil sebanyak $3 \mathrm{~mL}$ untuk dianalisis kadar pewarna alami secara gravimetri. Selanjutnya endapan yang terbentuk yang merupakan biomassa dipisahkan dari ekstrak dan dianalisis kandungan biomassa secara gravimetri. Dengan demikian pertumbuhan mikroorganisme atau terbentuknya biomassa, dan penurunan kandungan zat warna alami dalam ekstrak sebagai fungsi waktu dapat ditentukan. Percobaan dilakukan dengan cara yang sama untuk 5 jenis pengawet lainnya dengan berbagai konsentrasi, yaitu: ekstrak temu kunci (Boesenbergia rotunda L.), ekstrak daun salam (Syzygium polyanthum), dan ekstrak daun bandotan (Ageratum conyzoides $L$.), masing-masing sebanyak $5 \mathrm{~mL}$ ekstrak bahan pengawet dalam $40 \mathrm{~mL}$ sampel ekstrak. Konsentrasi ekstrak temu kunci 0,0148 gram $/ \mathrm{mL}$. Konsentrasi ekstrak daun salam 0,018 gram $/ \mathrm{mL}$. Konsentrasi ekstrak daun bandotan 0,03206 gram $/ \mathrm{mL}$. Adapun kitosan dengan konsentrasi 0,025 gram $/ \mathrm{mL}$ asam asetat $20 \%$ ditambahakan dengan perbandingan 2 $\mathrm{mL} / 40 \mathrm{~mL}$ ekstrak, formalin dengan konsentrasi $1 \%$ vol/vol ditambahkan dengan perbandingan $0.6 \mathrm{~mL} / 40$ mL ekstrak. 


\section{Hasil dan Pembahasan}

\subsection{Screening pemilihan jenis bahan pengawet}

Data kuantitatif hasil pengamatan penurunan konsentrasi pewarna alami dalam ekstrak untuk 10 hari penyimpanan, untuk penambahan berbagai jenis zat pengawet, dibandingkan dengan konsentrasi pewarna alami dalam ekstrak mula-mula yaitu sebesar 0,0168 $\mathrm{g} / \mathrm{mL}$, disajikan dalam Gambar 5.

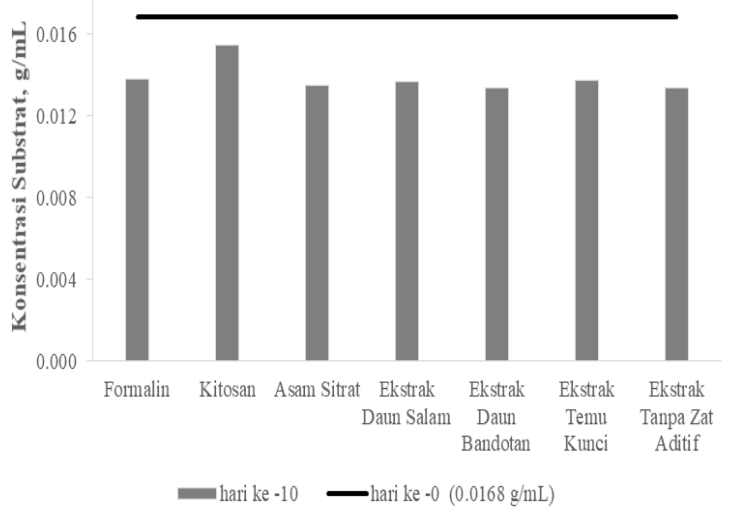

Gambar 5. Konsentrasi pewarna alami dalam ekstrak selama 10 hari penyimpanan untuk berbagai jenis zat pengawet yang ditambahkan

Tabel 1. Hasil analisis kualitatif terhadap kenampakan fisis ekstrak selama penyimpanan dan hasil pewarnaan kain

\begin{tabular}{|c|c|c|}
\hline $\begin{array}{c}\text { Bahan } \\
\text { Pengawet }\end{array}$ & $\begin{array}{l}\text { Kenampakan } \\
\text { fisis ekstrak }\end{array}$ & Hasil pewarnaan kain \\
\hline Formalin & $\begin{array}{c}\text { Tidak } \\
\text { terbentuk flok }\end{array}$ & $\begin{array}{c}\text { Hasil pewarnaan } \\
\text { menyerupai hasil } \\
\text { pewarnaan dengan } \\
\text { ekstrak awal }\end{array}$ \\
\hline Kitosan & $\begin{array}{l}\text { Tidak } \\
\text { terbentuk flok }\end{array}$ & $\begin{array}{c}\text { Hasil pewarnaan } \\
\text { menyerupai hasil } \\
\text { pewarnaan dengan } \\
\text { ekstrak awal }\end{array}$ \\
\hline $\begin{array}{l}\text { Asam } \\
\text { Sitrat }\end{array}$ & $\begin{array}{l}\text { Terbentuk } \\
\text { sedikit flok }\end{array}$ & $\begin{array}{l}\text { Hasil pewarnaan lebih } \\
\text { muda dibanding } \\
\text { ekstrak awal (pudar) }\end{array}$ \\
\hline $\begin{array}{l}\text { Ekstrak } \\
\text { Daun } \\
\text { Salam }\end{array}$ & $\begin{array}{c}\text { Terbentuk } \\
\text { banyak flok }\end{array}$ & $\begin{array}{l}\text { Hasil pewarnaan lebih } \\
\text { muda dibanding } \\
\text { ekstrak awal (pudar) }\end{array}$ \\
\hline $\begin{array}{c}\text { Ekstrak } \\
\text { Temu } \\
\text { Kunci }\end{array}$ & $\begin{array}{l}\text { Terbentuk } \\
\text { sedikit flok }\end{array}$ & $\begin{array}{l}\text { Hasil pewarnaan lebih } \\
\text { muda dibanding } \\
\text { ekstrak awal (pudar) }\end{array}$ \\
\hline $\begin{array}{l}\text { Ekstrak } \\
\text { Daun } \\
\text { Bandotan }\end{array}$ & $\begin{array}{c}\text { Terbentuk } \\
\text { banyak flok }\end{array}$ & $\begin{array}{l}\text { Hasil pewarnaan lebih } \\
\text { muda dibanding } \\
\text { ekstrak awal (pudar) }\end{array}$ \\
\hline $\begin{array}{c}\text { Ekstrak } \\
\text { tanpa } \\
\text { bahan } \\
\text { pengawet }\end{array}$ & $\begin{array}{c}\text { Terbentuk } \\
\text { banyak flok }\end{array}$ & $\begin{array}{l}\text { Hasil pewarnaan lebih } \\
\text { muda dibanding } \\
\text { ekstrak awal (pudar) }\end{array}$ \\
\hline
\end{tabular}

Selain analisis kuantitatif penurunan konsentrasi pewarna alami dalam ekstrak selama 10 hari penyimpanan terhadap konsentrasi mula-mula, juga dilakukan analisis kualitatif. Analisis kualitatif dilakukan dengan mengamati kenampakan fisis ekstrak selama penyimpanan dan pengamatan terhadap kualitas hasil pewarnaan kain menggunakan masing-masing ekstrak setelah disimpan selama 10 hari tersebut. Hasil analisis kualitatif disajikan dalam Tabel 1 .

Berdasarkan analisis kuantitatif dan kualitatif, dapat disimpulkan bahwa ekstrak zat warna dari gambir membutuhkan bahan pengawet selama penyimpanan. Hal ini sesuai dengan pengalaman empiris para pengrajin yang menyatakan bahwa kelemahan pewarna alami gambir adalah mudahnya tumbuh jamur pada saat aplikasi pada kain dan benang.

Berdasarkan hasil tahap screening pemilihan jenis bahan pengawet, sebagaimana disajikan dalam Gambar 5 dan Tabel 1, dapat dinyatakan bahwa bahan pengawet kitosan dan formalin lebih efektif dibanding asam sitrat, ekstrak daun salam, ekstrak temu kunci, dan ekstrak daun bandotan. Hasil ini sesuai dengan hasil penelitian Rahayuningsih dkk. (2016) yang menyatakan formalin dan kitosan merupakan pengawet yang baik untuk ekstrak zat warna alami dari kulit buah Jalawe.

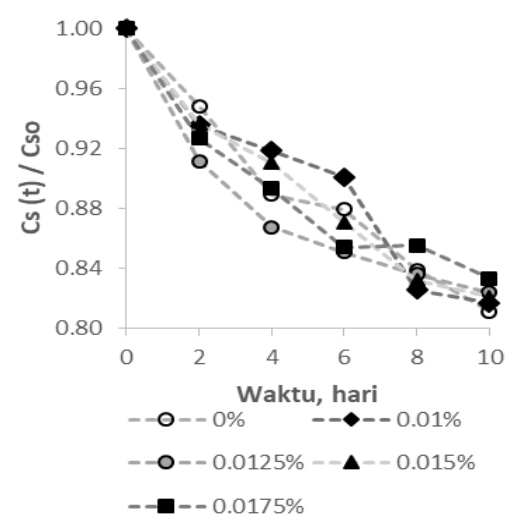

(a)

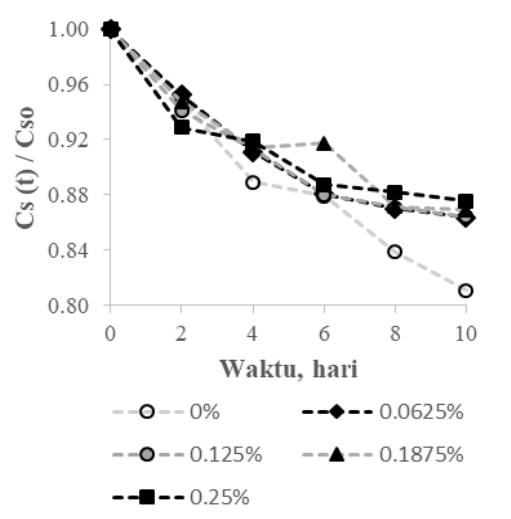

(b)

Gambar 6. Hubungan konsentrasi pewarna alami dan waktu untuk berbagai kadar bahan pengawet. (a) Larutan formalin dalam air dan (b) larutan kitosan dalam asam asetat 


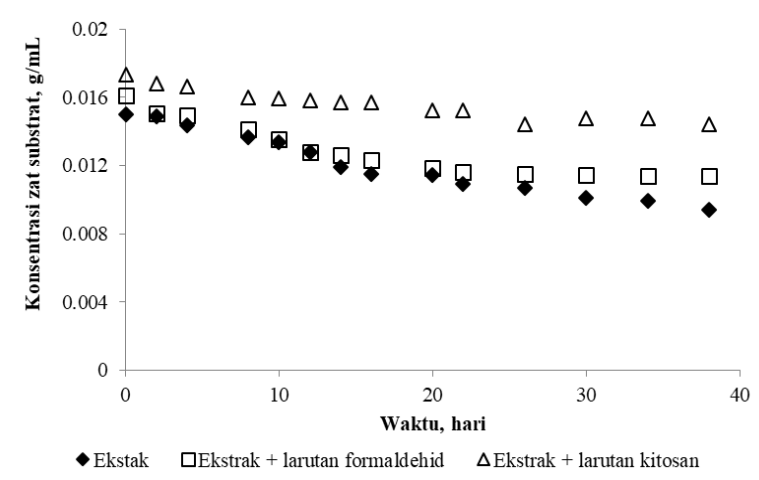

(a)

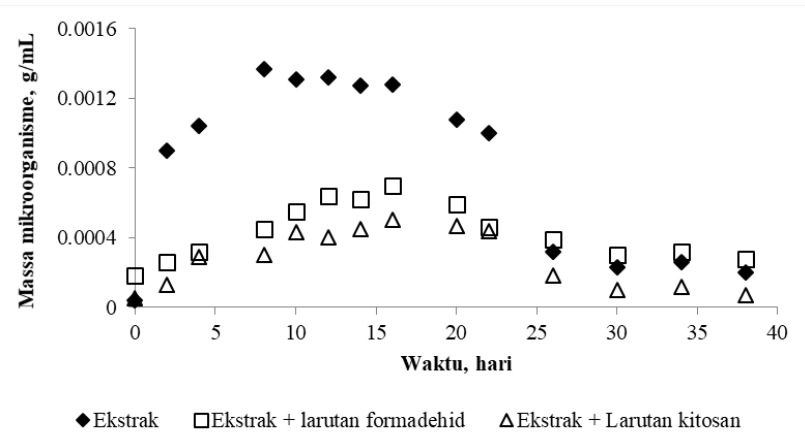

(b)

Gambar 7. Hubungan konsentrasi zat warna alami dan biomassa terhadap waktu pada ekstrak gambir dengan konsentrasi bahan pengawet formalin $0,0175 \%(\mathrm{v} / \mathrm{v})$ dan kitosan 0,25\% (v/v). (a) pewarna alami (substrat) dan (b) biomassa

\subsection{Penentuan konsentrasi efektif pengawet dalam ekstrak}

Gambar 6 menyatakan hubungan konsentrasi pewarna alami dan waktu untuk berbagai kadar bahan pengawet formalin dan kitosan.

Kurva konsentrasi pewarna alami terhadap waktu untuk konsentrasi formalin $0,0175 \%$, pada waktu lebih dari 6 hari sudah mulai landai dan lebih tinggi dari nilai konsentrasi lainnya. Adapun kurva yang lainnya masih tetap menurun. Pada penelitian Rahayuningsih dkk. (2016), formalin juga digunakan sebagai zat aditif dalam pengawetan ekstrak zat warna alami dari kulit buah jelawe, di mana formalin dengan kadar 0,015\% dalam ekstrak kulit buah jelawe merupakan konsentrasi yang paling efektif dalam menghambat pertumbuhan mikroorganisme dalam pengamatan selama tujuh hari penyimpanan. Pada penelitian ini konsentrasi formalin 0,0175\% merupakan konsentrasi yang efektif untuk pengawet ekstrak gambir.

Kurva konsentrasi pewarna alami dalam ekstrak terhadap waktu dengan penambahan bahan pengawet kitosan pada berbagai konsentrasi memberikan kurva yang landai mulai hari ke 6. Adapun untuk kurva konsentrasi pewarna alami dalam ekstrak terhadap waktu tanpa penambahan pengawet masih tetap menurun terjal sampai hari ke 10. Ekstrak pewarna alami dengan konsentrasi kitosan 0,25\% memberikan tren penurunan paling landai dibandingkan dengan konsentrasi lainnya. Konsentrasi kitosan 0,25\% merupakan konsentrasi yang efektif untuk pengawet ekstrak gambir sehingga konsentrasi tersebut ditinjau lebih lanjut untuk menentukan laju degradasi substrat.

3.3. Penentuan laju degradasi zat warna alami dalam ekstrak gambir

Hasil pengamatan laju perubahan konsentrasi substrat dan biomassa disajikan dalam Gambar 7.a. dan Gambar 7.b. Berdasarkan Gambar 7.a. dapat dinyatakan konsentrasi zat warna alami (substrat) terhadap waktu pada ekstrak gambir dengan konsentrasi bahan pengawet kitosan 0,25\% memiliki laju penurunan yang lebih landai dibandingkan dengan ekstrak dengan pengawet formalin. Adapun konsentrasi zat warna alami (substrat) terhadap waktu pada ekstrak gambir dengan konsentrasi bahan pengawet formalin $0,0175 \%$ mulai landai setelah waktu 20 hari, dibandingkan dengan ekstrak tanpa pengawet. Pada Gambar 8.b. dapat dilihat bahwa penambahan pengawet formalin $0,0175 \%$ dan kitosan $0,25 \%$ dapat menghambat laju pertumbuhan mikroorganisme. Berdasarkan Gambar 7.a. dan Gambar 7.b. dapat disimpulkan bahwa semakin besar pertumbuhan mikroorganisme maka akan semakin besar penurunan konsentrasi substrat. Hal tersebut sudah sesuai dengan teori bahwa nutrisi untuk pertumbuhan berasal dari substrat pada ekstrak gambir.

Laju biodegradasi pewarna alami dalam ekstrak gambir, dengan konsentrasi bahan pengawet formalin $0,0175 \%$ dan kitosan $0,25 \%$, ditentukan berdasarkan data hubungan konsentrasi substrat dan biomass terhadap waktu tersebut. Konstanta laju biodegradasi yaitu $\mu_{0}, K s, k_{d}$ dan $Y i$, ditentukan dengan pencocokan kurva konsentrasi substrat dan biomass terhadap waktu hasil pengamatan laboratorium dengan hasil simulasi menggunakan persamaan simultan (1), (2), (3), (4), dan (5). Hasil fitting kurva disajikan dalam Gambar 8, Gambar 9, dan Gambar 10.

Tabel 2 menyajikan nilai-nilai konstanta model kinetika yang dijabarkan dalam Persamaan (1) dan Persamaan (2). Nilai parameter $\mu_{0}$ menunjukkan laju pertumbuhan mikroorganisme. Nilai $\mu_{0}$ yang paling rendah teramati pada ekstrak dengan penambahan $0,25 \%$ pengawet kitosan. Hal ini menunjukkan bahwa penghambatan mikroorganisme oleh kitosan paling besar dibanding formaldehid dan besarnya penghambatan cukup signifikan jika dibandingkan dengan ekstrak tanpa pengawet.

Nilai konstanta $K s$ menyatakan efektivitas afinitas mikroorganisme dengan substrat. Pada umumnya dalam Persamaan Monod, nilai Ks yang jauh lebih kecil daripada konsentrasi substrat mengindikasikan bahwa substrat tidak terlalu berpengaruh pada pertumbuhan mikroorganisme. Dalam penelitian ini, konsentrasi substrat tertinggi adalah $0,0175 \mathrm{~g} / \mathrm{mL}$ sedangkan nilai $K s$ berkisar 0,03-0,053 g/mL. Nilai $K s$ yang semakin kecil (relatif terhadap konsentrasi 
substrat) menunjukkan kecenderungan laju pertumbuhan yang mendekati laju maksimal. Nilai $K s$ dalam Tabel 2 menunjukkan bahwa penambahan pengawet meningkatkan nilai $K s$, yang berarti mengindikasikan laju pertumbuhan yang lebih rendah daripada laju maksimumnya. Berdasarkan nilai $K s$, maka pengawet kitosan memberikan penghambatan pertumbuhan yang lebih baik dibanding dengan formaldehid.

Nilai $k_{d}$ menunjukkan laju kematian mikroorganisme. Tabel 2 menunjukkan bahwa nilai $k_{d}$ dengan penambahan pengawet justru lebih rendah daripada nilai $k_{d}$ tanpa penambahan pengawet. Pembandingan nilai absolut $k_{d}$ bisa memberikan kesimpulan yang keliru karena laju pertumbuhan pada ketiga kasus yang dibandingkan dalam Tabel 2 berbeda satu sama lain. Pembandingan lebih objektif dilakukan berdasarkan rasio antara nilai $k_{d}$ dan $\mu_{0}$ yang mengindikasikan prosentase laju kematian mikroorganisme terhadap laju pembentukan organisme baru. Tabel 2 menunjukkan nilai rasio $k_{d}$ dan $\mu_{0}$ yang hampir sama nilainya untuk semua variasi pengawet.
Tetapi laju pertumbuhan yang paling lambat pada ekstrak dengan pengawet kitosan, maka efek kematian paling signifikan dibandingkan pada kedua variasi yang lain. Hal ini menunjukkan bahwa kemungkinan mekanisme penghambatan oleh kitosan lebih ke arah menghambat perkembangbiakan mikroorganisme dan bukan membunuh mikroorganisme yang sudah terbentuk.

Dugaan mekanisme penghambatan tersebut diperkuat dengan nilai $Y_{i}$ yang menunjukkan rasio antara jumlah sel yang terbentuk terhadap jumlah substrat yang dikonsumsi. Penambahan pengawet menghasilkan jumlah sel yang lebih sedikit per satuan massa substrat yang dikonsumsi jika dibandingkan dengan ekstrak tanpa pengawet. Jika dibandingkan antara formaldehid dan kitosan, formaldehid ternyata menghasilkan nilai $Y i$ yang lebih rendah. Walaupun demikian, laju pertumbuhan mikroorganisme dalam ekstrak dengan formaldehid masih lebih tinggi daripada ekstrak dengan kitosan. Oleh karena itu, kitosan merupakan pilihan yang lebih baik daripada formaldehid.

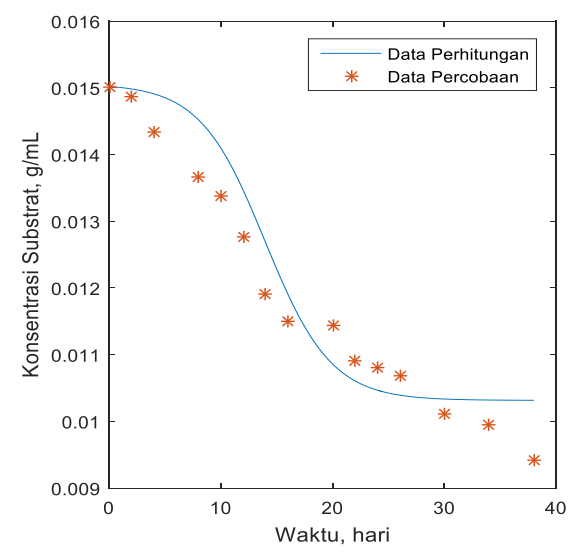

(a)

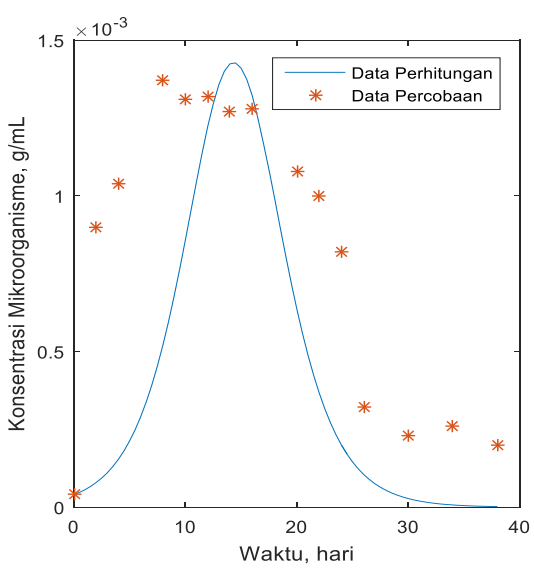

(b)

Gambar 8. Hasil pencocokan kurva konsentrasi (a) substrat dan (b) biomass terhadap waktu hasil pengamatan laboratorium dengan hasil simulasi untuk ekstrak tanpa pengawet

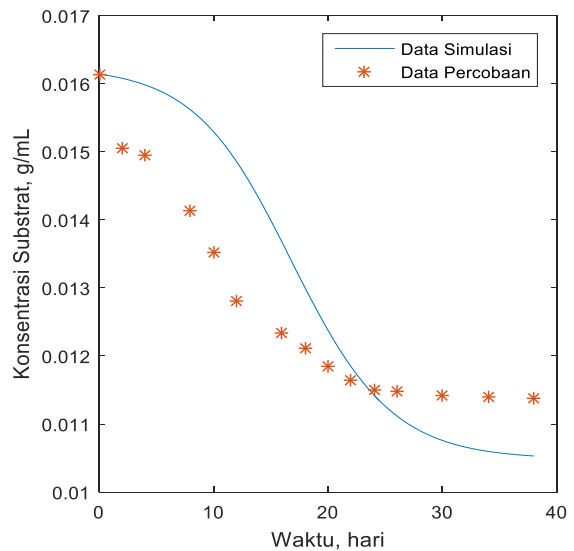

(a)

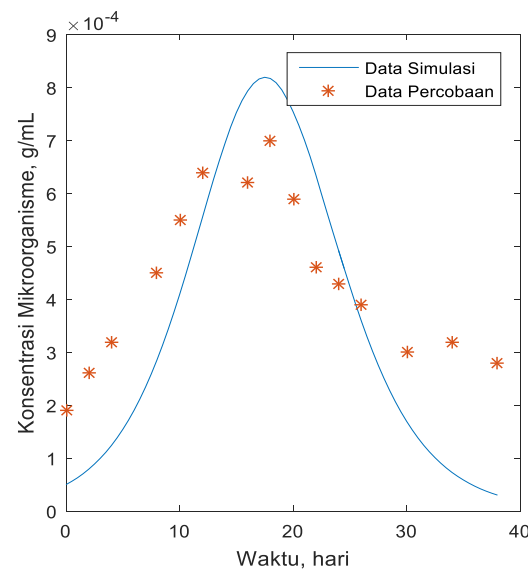

(b)

Gambar 9. Hasil pencocokan kurva konsentrasi (a) substrat dan (b) biomass terhadap waktu hasil pengamatan laboratorium dengan hasil simulasi untuk bahan pengawet formalin 


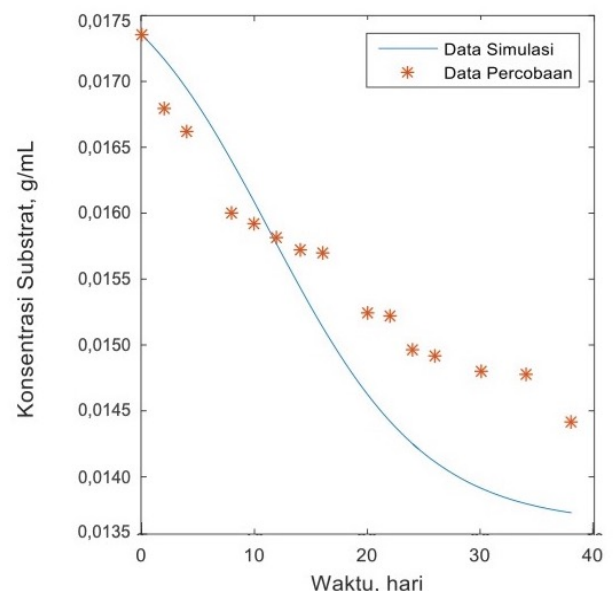

(a)

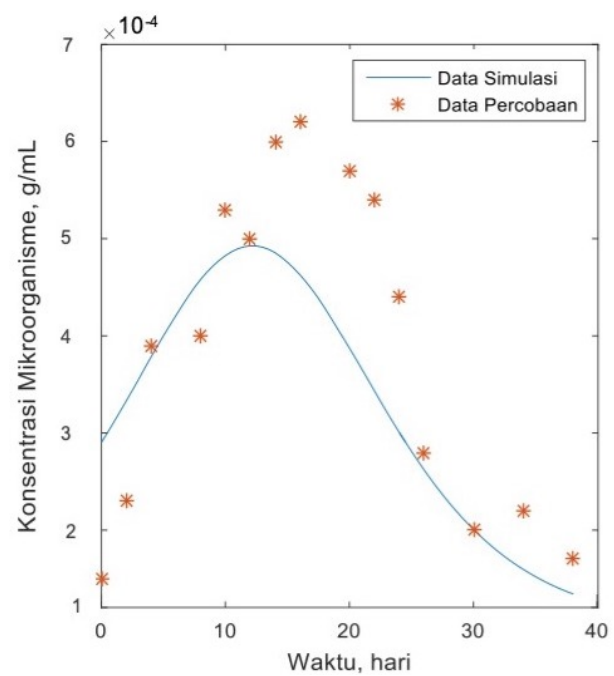

(b)

Gambar 10. Hasil pencocokan kurva konsentrasi substrat dan biomass terhadap waktu hasil pengamatan laboratorium dengan hasil simulasi untuk pengawet kitosan

Tabel 2. Nilai Konstanta $\mu_{0}, K s, k_{d}$ dan $Y i$

\begin{tabular}{cccccc}
\hline Sistem & $\begin{array}{c}\mu 0, \\
\text { hari } \\
1\end{array}$ & $\begin{array}{c}K s, \\
\mathrm{~g} / \mathrm{mL}\end{array}$ & $\begin{array}{c}k_{d}, \\
\text { hari } \\
-1\end{array}$ & $\begin{array}{c}k_{d} / \mu 0, \\
\%\end{array}$ & $Y i$ \\
\hline $\begin{array}{c}\text { Ekstrak tanpa } \\
\text { pengawet }\end{array}$ & 8,7 & 0,030 & 2,56 & 29,5 & 9,03 \\
$\begin{array}{c}\text { Ekstrak dengan } \\
\text { 0,0175\% } \\
\text { pengawet }\end{array}$ & 6,3 & 0,048 & 1,35 & 21,4 & 3,31 \\
$\begin{array}{c}\text { formaldehid } \\
\text { Ekstrak dengan } \\
\text { 0,25\% }\end{array}$ & 6,0 & 0,053 & 1,36 & 22,7 & 3,31 \\
$\begin{array}{c}\text { pengawet } \\
\text { kitosan }\end{array}$ & & & & & \\
\hline
\end{tabular}

Tabel 3. Waktu asimtot degradasi substrat

\begin{tabular}{cccc}
\hline Sistem & $\begin{array}{c}\text { Konsentrasi } \\
\text { substrat } \\
\text { mula-mula, } \\
\mathrm{g} / \mathrm{mL}\end{array}$ & $\begin{array}{c}\text { Waktu } \\
\text { asimtot, } \\
\text { hari }\end{array}$ & $\begin{array}{c}\text { Penurunan } \\
\text { konsentrasi, } \\
\%\end{array}$ \\
\hline $\begin{array}{c}\text { Ekstrak tanpa } \\
\text { pengawet }\end{array}$ & 0,015 & 38 & 40 \\
$\begin{array}{c}\text { Ekstrak dengan } \\
0,0175 \%\end{array}$ & 0,016 & 59 & 35 \\
pengawet & & & \\
formaldehid & & & \\
$\begin{array}{c}\text { Ekstrak dengan } \\
\text { 0,25\% }\end{array}$ & 0,017 & 77 & 21 \\
pengawet & & & \\
kitosan & & & \\
\hline
\end{tabular}

Selain evaluasi berdasarkan nilai-nilai konstanta dalam model kinetika, sering kali digunakan nilai waktu paroh sebagai parameter laju degradasi. Waktu paroh adalah waktu dimana nilai rasio konsentrasi substrat pada waktu tertentu dengan konsentrasi substrat pada waktu mula-mula bernilai 0,5. Berdasarkan hasil perhitungan yang disajikan pada Tabel 3, dapat dinyatakan bahwa terjadi kondisi asimtotis sebelum waktu paroh tercapai. Nilai asimtotis merupakan nilai konsentrasi substrat yang tidak berubah terhadap waktu. Kondisi ini dapat tercapai karena laju pertumbuhan mikroorganisme sama dengan laju kematian mikroorganisme. Untuk itu dapat dinyatakan bahwa dengan penambahan bahan pengawet kitosan sebesar $0,25 \%$ volum dapat memperlambat laju degradasi dan penurunan konsentrasi substrat paling kecil. Berdasarkan data ini dapat disimpulkan bahwa selama penyimpanan konsentrasi pewarna alami pada ekstrak gambir dapat dipertahankan pada konsentrasi 65\%, dengan penambahan bahan formaldehid pada ekstrak gambir dengan konsentrasi bahan pengawet formaldehid dalam ekstrak sebesar 0,0175\%volum. Adapun dapat dipertahankan pada konsentrasi 79\%, dengan penambahan bahan kitosan pada ekstrak gambir dengan konsentrasi bahan pengawet kitosan dalam ekstrak sebesar 0,25\%volum. Pada waktu 25 hari konsentrasi biomass sangat rendah atau pada fase kematian dan asimtotis. Pada fase ini terjadi laju kematian komponen biotik lebih besar dari laju pertumbuhannya atau bahkan laju pertumbuhannya mendekati nol. Karena pada penelitian ini, persediaan substrat nutrisi masih tersedia maka kematian mikroorganisme kemungkinan karena teracuni oleh akumulasi asam organik dan zat toksik yang terbentuk selama fase pertumbuhan mikroorganisme yang mengakibatkan mikroorganisme banyak yang mati. Hal tersebut mengakibatkan konsentrasi substrat konstan setelah waktu tertentu (Fogler, 2004).

\section{Kesimpulan}

Larutan formaldehid dalam air dan kitosan dalam larutan asam asetat $2 \%$ efektif dapat menghambat reaksi biodegradasi zat warna alami dari ekstrak 
gambir, dibandingkan bahan pengawet lainnya, yaitu: asam sitrat, ekstrak daun salam (Syzygium polyanthum), ekstrak temu kunci (Boesenbergia rotunda L.), dan ekstrak daun bandotan (Ageratum conyzoides L.). Jumlah formalin dan kitosan yang ditambahkan dalam ekstrak pewarna alami dari gambir yang paling efektif adalah masing-masing 0,0175\% volum dan $0,25 \%$ volum. Penambahan pengawet kitosan sebesar $0,25 \%$ volum dapat memperlambat laju degradasi, memperkecil penurunan konsentrasi pewarna alami dalam ekstrak, sehingga dapat dipertahankan pada konsentrasi 79\% setelah waktu penyimpanan 77 hari. Penambahan bahan pengawet formaldehid dalam ekstrak sebesar 0,0175\%volum, dapat mempertahankan konsentrasi pewarna alami pada ekstrak gambir sebesar $65 \%$ setelah waktu penyimpanan 59 hari. Adapun bila tanpa bahan pengawet konsentrasi pewarna alami pada ekstrak gambir hanya dapat dipertahankan sebesar $60 \%$ setelah waktu 38 hari.

\section{Ucapan Terima Kasih}

Ucapan terimakasih disampaikan kepada Ketua Departemen Teknik Kimia, Fakultas Teknik, UGM atas dana dan fasilitas yang disediakan, sehingga penelitian dan publikasi ini dapat dilakukan.

\section{Daftar Pustaka}

Adjou, E.; Dahouenon, E.A.; Degnon, R.; Sohounloue, D.K., Investigations on Bioactivity of Essential Oil of Ageratum conyzoides L., from Benin Against The Growth of Fungi and Aflatoxin Production. International Journal of Pharmaceutical Sciences Review and Research, 2012, 13(1), 143-148.

Arunachalam, M.; Mohan, M.; Mohan, N.; Mahadevan, A., Biodegradation of Catechin. Proceedings-Indian National Science Academy Part B, 2003, B69(4), 353370.

Dhalimi, A., Permasalahan Gambir (Uncaria gambir L.) di Sumatera Barat dan Alternatif Pemecahannya. Perspektif, 2006, 5(1), 46-59.

Fogler, H.S., Elements of Chemical Reaction Engineering, $3^{\text {rd }}$ ed. New Delhi: Pearson Educational, Inc., 2004.

Grosvenor, P.W.; Supriono, A.; Gray, D.O., Medicinal Plants from Riau Province, Sumatra, Indonesia Part 2:
Antibacterial and Antifungal Activity. Journal of ethnopharmacology, 1995, 45(2), 97-111.

Guynot, M.E.; Marin, S.; Setu, L.; Ramos, A., Screening for Antifungal Activity of Some Essential Oil Against Common Spoilage Fungi of Bakery Products. Food Science and Technology International, 2005, 11(1), 25-32.

Hagerman, A.E.; Robbins, C.T.; Weerasuriya, Y.; Wilson, T.C.; McArthur, C., Tannin Chemistry in Relation to Digestion. Journal of range management, 1992, 45(1), 57-62.

Hasanudin, M.; Widjiyati; Sumardi; Mudjini; Setioleksono, H.; Pamungkas, W., Laporan Penelitian Penerapan Zat Warna Alam dan Kombinasinya pada Produk Batik dan Tekstil Kerajinan. Balai Besar Penelitian dan Pengembangan Industri Kerajinan dan Batik, Yogyakarta, 2001.

Hayani, E., Analisis Kadar Katekin dari Gambir dengan Berbagai Metode. Buletin Teknik Pertanian, 2003, 8(1), 31-33.

Nazir, N., Gambir: Budidaya, Pengolahan, dan Prospek Diversifikasinya. Yayasan Hutanku, Padang, 2000.

Norajit, K.; Laohakunjit, N.; Kerdshoehuen, O., Antibacterial Effect of Five Zingiberaceace Essential Oils. Molecules, 2007, 12, 2047-2060.

Rahayuningsih, E.; Wijayanto, A.; Nurfitasari, P., Preservation of Natural Colorant Extract of Jelawe Fruit Peel (Termininalia bellirica) in Water-Based Solution. Indonesian Journal of Chemistry, 2016, 16(3), 315-321.

Sediawan, W.B.; Prasetya, A., Pemodelan Matematis dan Penyelesaian Numeris dalam Teknik Kimia. Yogyakarta: Andi Offset, 1997.

Sumono, A.; Wulan, A.S., The Use of Bay Leaf (Eugenia polyantha Wight) in Dentistry. Dental Journal, 2008, 41(3), 147-150.

Younes, I.; Rinaudo, M., Chitin and Chitosan Preparation from Marine Sources, Structure, Properties and Applications. Marine drugs, 2015, 13, 1133-1174. 